\title{
Manfaat Dan Mekanisme Penyelesaian Klaim Asuransi Prudential
}

\author{
Ratna Syamsiar
}

Dosen Bagian Hukum Perdata Fakultas Hukum Universitas Lampung

\begin{abstract}
Abstrak
PT Prudential Life Assurance memberikan perlindungan bagi tertanggung disertai dengan investasi dengan jangka waktu yang sangat lama memiliki risiko yang tinggi. Hal ini dikarenakan di samping perusahaan asuransi jiwa sebagai penanggung memiliki risiko juga adanya risiko yang berasal dari investasi yang sensitif dengan adanya krisis global yang tidak bisa dipastikan kapan akan terjadi. Penelitian ini difokuskan pada manfaat dan mekanisme asuransi prudential. Metode penelitian menggunakan normatif empiris, dengan tipe penelitian deskriptif. Pendekatan masalah dalam penelitian ini adalah pendekatan hukum non judicial case study yaitu pendekatan studi pada PT Prudential Life Assurance di Bandar Lampung dengan mengkaji pelaksanaan perjanjian asuransi jiwa. Hasil penelitian menunjukkan bahwa manfaat PT Prudential Life Assurance memberikan perlindungan selama 99 (sembilan puluh sembilan) tahun dikombinasikan dengan investasi. Jika hasil investasi selama masa kewajiban pembayaran premi tidak mencukupi maka polis dapat berstatus lewat waktu (lapsed) bahkan batal dan tidak mempunyai manfaat. Keluarga sebagai ahli waris akan mendapatkan memiliki dana yang cukup untuk biaya pendidikan anak-anak. Seandainya tertanggung meninggal dunia secara tiba-tiba atau mengalami sakit harus dirawat inap sampai cacat total akibat penyakit sehingga tidak dapat bekerja lagi. Manfaat lain untuk membiayai biaya pendidikan atau memenuhi kebutuhan tunjangan hari tua bagi tertanggung. Mekanisme klaim asuransi prudential melalui proses yang telah ditentukan di dalam polis dan sudah disiapkan bagian klaim. Tertanggung diwajibkan mengisi seluruh formulir klaim yang sudah ditentukan. Apabila tertanggung kecelakaan/sakit menyiapkan dokumen penunjang (kwitansi asli, hasil rekaman medis, hasil laboratorium, laporan kepolisian). Selanjutnya jika terjadi peristiwa meninggal dunia, ahli waris menyerahkan surat keterangan dokter klaim/Rumah Sakit dan perusahaan akan menvalidasi seluruh dokumen dan hasil investasinya. Selanjutnya dana ditransfer ke rekening tertanggung atau ahli waris terkait.
\end{abstract}

\section{Kata kunci: manfaat, mekanisme klaim, asuransi prudential}

\section{Pendahuluan}

Setiap orang pasti memiliki risiko terhadap jiwa dan raga yang perlu dilindungi dari bahaya yang tidak dapat diprediksikan. Kekhawatiran tersebut mendorong seseorang untuk mengusahakan perlindungan terhadap dirinya sendiri atau keluarganya dari berbagai bahaya yang mengancam, namun jika terjadi suatu keadaan yang tidak diinginkan seperti kematian, sakit atau bahkan cacat, akan lebih baik 
jika seseorang yang menderita tersebut mendapat bantuan dana atau santunan dari pihak-pihak tertentu untuk dapat membantu suatu perubahan keadaan financial dari suatu keluarga. Oleh karena itu, hal ini menunjukkan pentingnya suatu pertanggungan keselamatan atas jiwa dan raga yang dimiliki bagi seseorang yang menderita dan keluarganya.

Selain itu kebutuhan biaya pendidikan anak-anak saat ini mengalami peningkatan signifikan, jaminan hari tua dapat diberikan oleh PT Prudential life (Prudential), apabila calon tertanggung menutup perjanjian dengan pihak penanggung.

Namun, perusahaan asuransi jiwa yang menyertakan investasi pada seluruh produk asuransinya masih jarang terutama perusahaan asuransi jiwa dalam negeri. Hal ini diakibatkan oleh rentannya investasi terhadap krisis perekonomian global yang tidak dapat diperkirakan kapan terjadi. Oleh karena itu, pengkombinasian antara investasi dan asuransi jiwa menyebabkan perjanjian asuransi jiwanya berbeda dari perjanjian asuransi jiwa tanpa investasi karena lebih banyak klausul yang diatur di dalamnya meliputi klausul mengenai asuransi jiwa dan klausul mengenai investasi.

Asuransi jiwa dan investasi pada dasarnya merupakan variasi bentuk dari jasa perlindungan yang ditawarkan oleh perusahaan asuransi jiwa. Perjanjian asuransi jiwa dan investasi diadakan oleh para pihak karena suatu kesepakatan, pihakpihak itu adalah penanggung, tertanggung dan pihak ketiga. Perusahaan asuransi jiwa sebagai pihak penanggung berjanji untuk menanggung suatu risiko yang dialihkan oleh pihak tertanggung kepadanya. Sedangkan tertanggung dan pihak ketiga adalah pihak yang mengalihkan risiko terhadap jiwa dan raga kepada penanggung dengan membayar sejumlah premi kepada penanggung.

Pada prakteknya, asuransi jiwa tidak hanya untuk memberikan perlindungan saja tetapi ada yang dikombinasikan antara asuransi jiwa dengan beasiswa pendidikan, tabungan ataupun dengan investasi.

Ada beberapa perusahaan asuransi jiwa di Indonesia yang mengeluarkan produk asuransi jiwa yang dikombinasikan dengan investasi. Tabungan tersebut merupakan hasil yang terbentuk dari investasi sehingga pada saat perjanjian asuransi berakhir, tertanggung tidak hanya mendapatkan pengembalian premi namun tertanggung mendapatkan hasil investasi.

Perusahaan asuransi jiwa yang mengkombinasikan antara asuransi jiwa dan investasi dalam hal ini adalah PT Prudential Life Assurance. Perusahaan asuransi jiwa ini memberikan perlindungan seumur hidup untuk tertanggungnya terhadap jiwa dan raga dalam hal sakit, cacat dan kematian. Asuransi jiwa yang disertai dengan investasi pada PT Prudential Life Assurance dilaksanakan dengan jangka waktu asuransi yang sangat lama memiliki risiko yang tinggi, hal ini dikarenakan di samping perusahaan asuransi jiwa sebagai penanggung memiliki risiko juga adanya risiko yang berasal dari investasi yang sensitif dengan adanya krisis global yang tidak bisa dipastikan kapan akan terjadi. Penelitian ini difokuskan manfaat dan mekanisme penyelesaian klaim asuransi PT Prudential Life. 


\section{PEMBAHASAN}

Pasal 4 Undang-Undang No.2 Tahun 1992 Tentang Usaha Perasuransian, mengatur bahwa usaha asuransi sebagaimana dimaksud dalam Pasal 3 huruf (a) hanya dapat dilakukan oleh perusahaan perasuransian, dengan ruang lingkup kegiatan sebagai berikut:

a) Perusahaan Asuransi Kerugian hanya dapat menyelenggarakan usaha dalam bidang asuransi kerugian, termasuk reasuransi;

b) Perusahaan Asuransi Jiwa hanya dapat menyelenggarakan usaha dalam bidang asuransi jiwa, dan asuransi kesehatan, asuransi kecelakaan diri, dan usaha anuitas, serta menjadi pendiri dan pengurus dana pensiun sesuai dengan peraturan perundangundangan dana pensiun yang berlaku;

c) Perusahaan Reasuransi hanya dapat menyelenggarakan usaha pertanggungan ulang.

Setiap perusahaan asuransi hanya dapat menjalankan satu jenis usaha asuransi dengan ruang lingkup kegiatan yang telah ditetapkan, setiap perusahaan asuransi tidak dibolehkan untuk memberikan beberapa perlindungan dari beberapa jenis asuransi sekaligus.

Jumlah jaminan asuransi jiwa itu termasuk unsur investasi, yang timbul dari perjanjian/kontrak (C. Arthur Williams Cs, 1998: 569). Kontrak atau yang telah disetujui tertanggung berisi pernyataan dikenal Polis. Asuransi jiwa pada dasarnya telah memiliki unsur investasi karena asuransi jiwa dapat memberikan jaminan keuangan dan perlindungan untuk beberapa tahun yang akan datang. Tertanggung sebagai debitur dapat dikatakan lalai jika peringatan atau pernyataan dari kreditur (penanggung) tentang saat selambat-lambatnya debitur wajib memenuhi prestasi. Apabila dilampauinya, maka debitur wanprestasi (Mariam Darus Badrulzaman, 2001: 18). Hal tersebut berakibat asuransi jiwa yang telah disetujui sebelumnya oleh kedua belah pihak di dalam polis menjadi tidak aktif.

Asuransi jiwa dikatakan memiliki fungsi investasi dan fungsi tabungan karena tertanggung akan menerima kembali premi yang dibayar selama menjadi tertanggung sebagai uang santunan ataupun sebagai uang pengembalian. Hal ini sama seperti menabung ataupun menginvestasikan sejumlah uang kepada suatu lembaga keuangan ataupun badan tertentu, yang bertujuan untuk memperoleh jaminan finansial dimasa mendatang atau di saat seseorang (suami/bapak/ibu) tidak mampu lagi untuk membantu finansial keluarga.

Hak dalam hukum perikatan timbul berdasarkan persetujuanpersetujuan dan merupakan hak relatif. Hak relatif ialah hak yang memberikan wewenang kepada seorang tertentu atau beberapa orang tertentu untuk menuntut agar supaya seseorang atau beberapa orang lain tertentu memberikan sesuatu, melakukan sesuatu atau tidak melakukan sesuatu (C.S.T. Kansil, 2002: 120).

Selanjutnya dijelaskan subjek hukum adalah pendukung hak dan kewajiban. Pendukung hak dan kewajiban disebut orang. Orang dalam arti hukum terdiri dari manusia pribadi dan badan hukum (Abdulkadir Muhammad, 2000: 27). 
Penanggung harus sebuah perusahaan berbadan hukum dapat berbentuk Perseroan Terbatas (PT), Perusahaan Perseroan (Persero), atau Koperasi. Tertanggung berstatus sebagai pemilik atau pihak yang berkepentingan atas jiwa dan raga yang diasuransikan. Tertanggung tidak harus sebuah perusahaan berbadan hukum, tetapi dapat sebagai perseorangan, persekutuan, atau badan hukum, baik sebagai perusahaan ataupun bukan perusahaan (Abdulkadir Muhammad, 2006: 8).

$$
\text { Setiap orang dapat }
$$
mengasuransikan jiwanya, asuransi jiwa dapat diadakan untuk kepentingan pihak ketiga. Asuransi jiwa dapat diadakan selama hidup atau selama jangka waktu tertentu yang ditetapkan dalam perjanjian (Abdulkadir Muhammad, 2006: 72).

Kewajiban terhadap pembayaran premi adalah kewajiban bagi tertanggung atau yang berkepentingan. Orang-orang yang dimaksud untuk membayar premi antara lain:

1. Orang yang namanya disebut di dalam polis;

2. Pemilik baru, jika ada peralihan kepemilikan;

3. Pemberi kuasa, pada pertanggungan oleh seorang pemegang kuasa "dengan pemberi kuasa" (H. Van Barneveld, 1980: 20).

Akibat hukum yang ditimbulkan oleh adanya suatu hubungan hukum dari suatu peristiwa hukum. Suatu hubungan hukum memberikan hak dan kewajiban yang telah ditentukan oleh undangundang, sehingga kalau dilanggar akan berakibat, bahwa orang yang melanggar itu dapat dituntut di muka pengadilan (Soedjono Dirdjosisworo,
2001: 131). Oleh karena itu bagi calon tertanggung sebelum menyetujui pastikan dahulu mengenai kewajiban pembayaran premi dan klaim jika terjadi evenemen.

Perusahaan Asuransi Jiwa adalah perusahaan yang memberikan jasa dalam penanggulangan risiko yang dikaitkan dengan hidup atau meninggalnya tertanggung. Sedangkan risiko adalah ketidaktentuan atau uncertainty yang mungkin menimbulkan kerugian (loss). Risiko adalah variasi potensial dalam pengeluaran. Ketika risiko hadir, pengeluaran tidak dapat diperkirakan dengan pasti. Pada akhirnya, risiko menimbulkan ketidakpastian (C. Arthur Williams Cs, 1998: 4).

Risiko merupakan aspek utama dan kehidupan menusia pada umumnya dan merupakan faktor penting dalam asuransi. Risiko merupakan kemungkinan penyimpangan harapan yang tidak menguntungkan, yaitu ketidakpastian suatu peristiwa yang tidak diinginkan. Peralihan risiko dengan pertanggungan/asuransi dalam bidang usaha-usaha besar dianggap suatu cara yang paling menguntungkan (Sri Rejeki Hartono, 2008: 60 - 73). Atas dasar ini banyak perusahaan asuransi yang memberi kemudahan dalam proses penyelesaian klaim termasuk Asuransi Prudential. Pernyataan tersebut telah dicantumkan dalam polis.

Polis adalah alat bukti terpenting untuk adanya dan besarnya pertanggungan $(\mathrm{H}$. Van Barneveld, 1980: 213). Polis adalah akta yang ditandatangani oleh tertanggung dan penanggung yang 
memiliki fungsi sebagai alat bukti dalam perjanjian.

Apabila mengalami penyakit yang tidak diberitahukan (non discolocure) sebelum polis diterbitkan tertanggung tidak mendapatkan manfaat (riders), kecuali penyakit diderita tertanggung setelah terbit polis. Untuk itu diharapkan calon tertanggung menutup perjanjian memberikan data dengan lengkap dan benar kepada penanggung.

Asuransi jiwa pada dasarnya memiliki fungsi investasi dan fungsi tabungan. Seperti yang diketahui, investasi merupakan suatu kegiatan penanaman atau penyertaan modal pada suatu lembaga keuangan atau perusahaan tertentu yang dalam jangka waktu tertentu akan menghasilkan profit atau laba, namun profit atau laba yang diharapkan belum tentu didapatkan investor. Sedangkan tabungan merupakan simpanan uang yang dalam jangka waktu tertentu akan mendapatkan bunga dan jaminan masa depan. Asuransi jiwa dikatakan memiliki fungsi investasi dan fungsi tabungan karena tertanggung akan menerima kembali premi yang dibayar selama menjadi tertanggung sebagai uang santunan ataupun sebagai uang pengembalian. Hal ini sama seperti menabung ataupun menginvestasikan sejumlah uang kepada suatu lembaga keuangan ataupun badan tertentu, yang bertujuan untuk memperoleh jaminan finansial dimasa mendatang atau disaat seseorang (suami/bapak atau istri/ibu) tidak mampu lagi untuk membantu finansial keluarga.

Manfaat asuransi prudential, keluarga akan dilindungi karena memiliki dana yang cukup seandainya tertanggung meninggal dunia secara tiba-tiba. Selain itu perlindungan kesehatan diberikan bagi tertanggung menderita sakit harus dirawat inap atau sampai pada tingkat mengalami cacat total. Akibat peristiwa tersebut mungkin tertanggung tidak dapat bekerja lagi atau pensiun dini.

Tertanggung

tidak mengharapkan terjadi evenemen, apabila telah menutup perjanjian dengan perusahaan prudential berarti telah melindungi dari produk asuransi jiwa. Manfaatnya bagi keluarga sebagai ahli waris mendapatkan perlindungan sangat berharga terhadap risiko yang tidak dapat diduga dalam bentuk uang pertanggungan.

Dengan demikian keluarga sebagai ahli waris minimal dapat mempertahankan standard kualitas apabila kepala keluarga/ibu sebagai tertanggung meninggal dunia. Apabila tidak menutup perjanjian asuransi jiwa terjadi evenemen, mengakibatkan standard kehidupan keluarga mungkin menurun.

Polis sebagi bukti perjanjian memberikan kompensasi finansial dalam bentuk uang pertanggungan banyak manfaatnya bagi keluarga sebagai ahli waris, apabila tertanggung meninggal dunia. Berarti kompensasi yang didapatkan sesuai dengan program yang ditutup dengan perjanjian oleh tertanggung.

Selain itu untuk membiayai pendidikan dasar sampai pendidikan tinggi saat ini, biaya pendidikan mengalami peningkatan signifikan. Untuk mengatasi hal tersebut tertanggung dapat menutup perjanjian dengan pihak penanggung. Dana pertanggungan dapat ditarik untuk biaya pendidikan, sesuai isi polis. 
Manfaat lain bagi tertanggung
untuk memenuhi kebutuhan
tunjangan hari tua. Tertanggung usia
produktif akan mendapatkan
penghasilan maksimal sesuai dengan
premi yang dibayar kepada
penanggung. Bagi tertanggung
memasuki masa pensiun atau
perjanjian berakhir, maka penanggung akan membayarkan sejumlah dana, seandainya sakit rawat jalan atau sakit yang tidak dilindungi oleh penanggung.

PT Prudential Life Assurance sebagai penanggung memperkuat manfaat dengan asuransi kesehatan, yang ditanggung biaya rawat inap, pengobatan. Hal ini merupakan produk baru untuk melindungi tertanggung terhadap 34 (tiga puluh empat) penyakit kritis di pasar Indonesia. Produk baru selama sisa hidupnya dapat mengklaim 3x (tiga) kali tanpa membayar premi tambahan. Apabila menginginkan hasil investasi lebih optimal, premi tambahan tetap diperlukan.

Apabila terjadi evenemen mengalami sakit yang serius kecuali fatal manfaat bagi tertanggung dapat mengklaim penanggung dengan proses mekanisme yang telah ditentukan oleh penanggung dalam polis.

Untuk menghindari kekeliruan dalam mengasuransikan diri pada asuransi jiwa dan investasi pada PT Prudential Life Assurance, sebaiknya tertanggung mempelajari klausul yang ada pada polis dan ringkasan ilustrasi polis mengenai asuransi jiwa dan investasi. Ketentuan mengenai investasi sangat mempengaruhi asuransi jiwa dan investasi. Selain itu, ketentuan mengenai investasi dalam ringkasan ilustrasi polis sebagian besar tidak dicantumkan dalam polis dan penanggung tidak memberikan jaminan terhadap risiko investasi.

Sebelum mengajukan klaim, tertangggung memiliki manfaat yang tercantum dalam polis. Berarti polis dam keadaan berlaku (aktif). Jika pembayaran premi tidak mencukupi maka polis dapat berstatus lewat waktu (lapsed) bahkan batal dan tidak mempunyai manfaat. Olehkarena itu tertangggung wajib memenuhi ketentuan yang berlaku seperti pembayaran premi dilengkapi dan perlindungan tetap berlangsung, sehingga tidak mengalami masa tunggu maupun pengecualian tertentu.

Pernyataan dalam polis menentukan keluarga memiliki dana yang cukup, seandainya terjadi risiko meninggal dunia secara tiba-tiba, biaya pendidikan atau tertanggung mengalami sakit dapat dirawat inap atau cacat tetap secara total akibat penyakit sehingga tidak dapat bekerja lagi.

Klaim asuransi bertujuan memberikan manfaat sesuai dengan ketentuan dalam polis. Proses klaim dapat dilakukan, jika tertanggung memperhatikan ketentuan penting mengenai pengajuan klaim. Manfaat bagi tertanggung untuk mengklaim penanggung dengan proses mekanisme yang sudah ditentukan oleh penanggung melalui tahap umum proses klaim. Untuk itu tertanggung diharapkan mencantumkan nomor polis dan nomor rekening bank atas nama pemegang polis/tertanggung atau ahli waris dengan jelas, lengkap dan benar.

Formulir disediakan telah oleh bagian klaim untuk diisi tertanggung/ahli waris, dari surat keterangan dokter yang merawat. Dokumen yang asli dapat 
dikembalikan setelah dilegalisir oleh PT Asuransi Prudential, jika diperlukan akan diminta data tambahan.

Mekanisme klaim Asuransi Prudential secara umum melalui langkah-langkah sebagai berikut:

1. Formulir klaim diisi tertanggung/pemegang polis/ahli waris (untuk klaim meninggal dunia) dengan menyertakan surat keterangan dokter.

2. Apabila klaim kecelakaan maka tertanggung/ahli waris menyerahkan dokumen penunjang kepada perusahaan seperti kwitansi asli, hasil rekaman medis, hasil laboratoriom, laporan kepolisian.

3. PT Asuransi Prudential akan menvalidasi seluruh dokumen pelengkap dan verifiksi tertanggung/ahli waris/dokter klaim/rumah sakit jika diperlukan. Selanjutnya dana ditransfer ke rekening pihak terkait.

\section{SIMPULAN}

Hasil penelitian menunjukan manfaat asuransi prudential bagi keluarga sebagai ahli waris memiliki dana yang cukup jika terjadi evenemen tertanggung meninggal dunia. Selain itu perlindungan jika mengalami sakit harus rawat inap atau cacat tetap secara total akibat penyakit sehingga tidak dapat bekerja lagi, sampai perlindungan seumur hidup bagi tertanggung. Manfaat lain untuk membiayai biaya pendidikan atau memenuhi kebutuhan tunjangan hari tua bagi tertanggung. Mekanisme penyelesaian klaim Asuransi Prudential bahwa tertanggung menyiapkan dokumen penunjang (kwitansi asli, hasil rekaman medis, hasil laboratorium, laporan kepolisian), jika mengalami musibah kecelakaan atau sakit. Apabila terjadi peristiwa meninggal dunia ahli waris menyerahkan surat keterangan dokter/Rumah Sakit. Perusahaan akan menvalidasi seluruh dokumen pelengkap dan verifikasi tertanggung/ahli waris/dokter klaim/ rumah sakit. Selanjutnya dana ditransfer kepada tertanggung atau ahli waris terkait.

\section{DAFTAR PUSTAKA}

Badrulzaman, Mariam Darus. 2001. Kompilasi Hukum Perikatan. PT Citra Aditya Bhakti. Bandung.

Barneveld, H. Van. 1980. Pengetahuan Asuransi. Alih Bahasa Strumphler cs. Bhratara Karya Aksara. Jakarta.

Dirdjosisworo, Soedjono. 2001. Pengantar Ilmu Hukum. PT RajaGrafindo Persada. Jakarta.

Hartono, Sri Rejeki. 2008. Hukum Asuransi dan Perusahaan Asuransi. Sinar Grafika. Jakarta.

Kansil, C.S.T. 2002. Pengantar Ilmu Hukum dan Tata Hukum Indonesia. Balai Pustaka. Jakarta.

Muhammad, Abdulkadir. 2004. Hukum dan Penelitian Hukum. PT Citra Aditya Bhakti. Bandung.

2006. Hukum Asuransi Indonesia. PT Citra Aditya Bhakti. Bandung.

Prakoso, Joko. 2000. Hukum Asuransi Indonesia. PT Rineka Cipta. Jakarta.

Williams, C. Arthur cs. 1998. Risk Management and Insurance. 
The McGraw-Hill

Companies, Inc. Singapore.

Materi PRU fast start Training,

Prudential 2007.

Kitab Undang-Undang Hukum

Perdata.

Kitab Undang-Undang Hukum

Dagang.

Undang-Undang Nomor 2 Tahun

1992 Tentang Usaha

Perasuransian. 